times after the incubator doors had been opened and closed (45 minutes to 45 hours), and in the centre of the highest and lowest shelf positions.

The $\mathrm{CO}_{2}$ concentration varied between $3 \cdot 1 \%$ and $7 \cdot 2 \%$ and in practice a rate of between 20 and $60 \mathrm{ml}$ per minute was found to support the growth of carbon dioxide requiring organisms such as newly isolated strains of $N$. gonorrhoeae and $\mathrm{Br}$. abortus (including biotype 2).

The cost of the modification totalled $£ 35$ and the running costs are approximately $10 \mathrm{p}$ per week.

Refereace

Lloyd, B. B. (1958). Development of Haldane's gas analysis apparatus. J. Physiol. (Lond.), 143, 5-6.

\section{An inexpensive and demountable walk-in incubator}

R. N. P. SUTTON AND G. AYLETT From the Departmenf of Microbiology, King's College Hospital Medicat School, and the Engineering Department, King' $\vec{D}$ College Hospital, London

In many areas of scientific work there are advantages in the use of walk-in incubators or "hot rooms" Those models which are available commercially are + however, expensive and, in the event of the rearrange ment of the laboratory in which they are housed ares extremely cumbersome to dis-assemble. During the development of the virus laboratory in the Depart: ment of Microbiology at King's College Hospita $\vec{z}$ Medical School considerations such as these led us to design an inexpensive and demountable hot room

\section{Structure of Hot Room}

The room is $2.4 \mathrm{~m} \times 1.75 \mathrm{~m}$, with a sloping roof, theheight of which ranges from $2.25 \mathrm{~m}$ to $2.6 \mathrm{~m}$; its volume is $10.5 \mathrm{~m}^{3}$. The roof slopes for ease of dusting and to avoid the collection of debris which often occurs on low-level flat roofs. The walls and roof consist of expanded polystyrene bonded to hardboard and are्尺 of about $5 \mathrm{~cm}$ thickness. They slot into and are sup ported by a framework of anodized extruded alu옥 minium girders of a type specially prepared for and supplied by Murr Internal Constructions Ltd. These girders are $\mathrm{H}$-shaped in cross section and the depth. of the slot on each side is about $1.25 \mathrm{~cm}$. The 1 B shape is modified at corners and at roof-walb junctions.

A single standard-size door is fitted; this fits into an aluminium frame which has a $7.5 \mathrm{~mm} \times 3 \mathrm{~mm}$ foam rubber sealing strip inserted, providing a tigh 9 fit at top and sides. At floor level we have found nos need for a draught excluder (but one could easily be installed) and we consider that it would be danger ously easy to trip over a raised floor 'rebate'.

\section{Heating Equipment}

The source of heat is a $3 \mathbf{~ k w}$ fan heater (type Generab Electrical Company H6448D) which is mounted in an upper corner of the room and set to direct the ain? flow downwards into the opposite lower corner. Ano Accuron unit controls the heat output of the fan vide a thermistor probe which is mounted behind the

Received for publication 6 January 1971. 
heater. This system is adequate for rooms with a capacity of up to about $16 \mathrm{~m}^{3}$ and for temperatures of up to $40^{\circ} \mathrm{C}$.

Temperature recording is by a Cambridge recorder which is mounted externally and, over a period of over one year since the installation of the hot room, the internal temperature has remained constantly at the set temperature $\left(37^{\circ} \mathrm{C}\right)$. Local temperature variations within the hot room have been observed but they are small (about $\pm 1^{\circ} \mathrm{C}$ ) and individual areas maintain a constant temperature. Frequent and prolonged opening of the door does not result in more than minor variations in temperature and a very rapid return takes place.

\section{Comment}

The cost of construction of the complete hot room was about $£ 310$, a figure which is substantially lower than that which one would expect in quotations from most sources for an insulated heated room of the same dimensions. It is also very much lower than the cost of individual incubators which could provide the same volume of heated space. The hot room can be dis-assembled very readily and modifications of size and shape could be made readily. It has been in service for over one year and has proved satisfactory in every way. We describe it in some detail as the component parts are readily available and as our solution may be helpful to other workers faced with the same problem of providing incubator space at low cost.

We are grateful to Murr Internal Constructions Ltd, 171-173 Worton Road, Isleworth, Middlesex, for the construction of the room, to Mr A. R. Taylor of Accuron Ltd, Cambridge, for advice on heating systems, and to Mr J. B. Anderson, FRICS, King's College Hospital, for much help. The expanded polystyrene panels were obtained from J. W. Roberts Ltd, Bolton, Lancs.

\section{A simple device for counting Jerne's plates to detect haemolytic antibody-forming cells}

\section{G. PETRACCHI, M. BENDINELLI, AND G. FALCONE From the Institute of Microbiology, University of Pisa, Italy}

The plaque technique introduced by Jerne, Nordin, and Henry (1963) is a method which serves for the detection and enumeration, among lymphoid cells, of those producing antibody of a given specificity. Dilute suspensions of lymphoid cells are plated in agar together with red cells. The cells which synthesize antibody against the red cells (or against other antigens previously attached to them) sensitize the surrounding red cells. When complement is added the antibody-red cell complexes lyse, leaving clear plaques.

We have developed a simple apparatus which greatly facilitates the counting of Jerne's plates. No benzidine staining of the plates is required. A diagram of the device is shown in Figure 1. A beam of parallel rays of light which hits a plate perpendicularly is diffused by the red cells incorporated in the agar: in the plaques, where the red cells are lysed, the light is

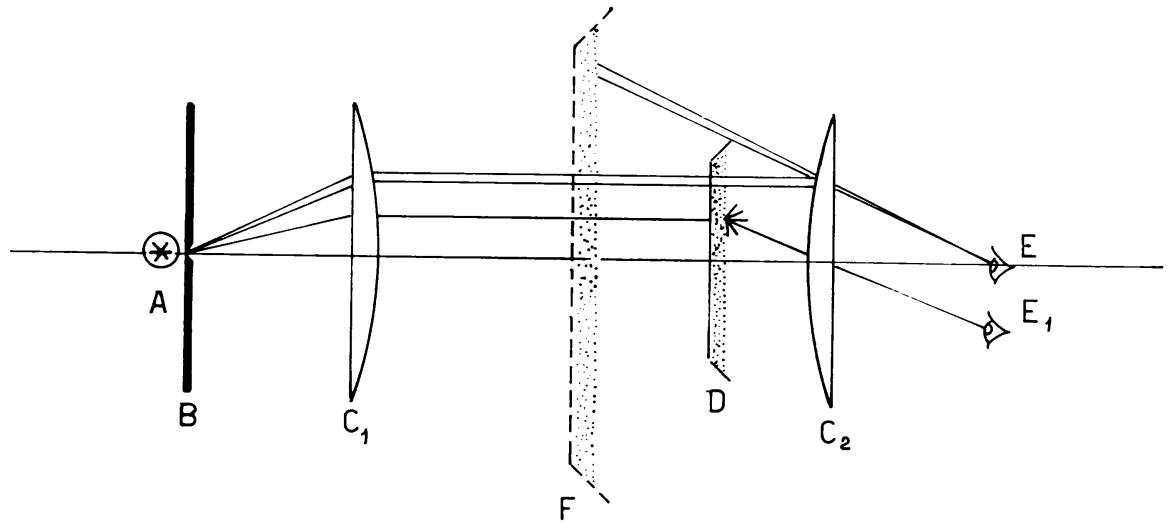

Fig. 1 Diagram of the device, A Lamp $(25 W) ; B$ Diaphragm supporting bone or ground glass $(\varnothing 5 \mathrm{~mm})$; $C_{1}$ and $C_{2}$ Lenses: focal length about $18 \mathrm{~cm}(\varnothing 10 \mathrm{~cm})$; $D$ plate; $E$ Image of diaphragm hole; $F$ Virtual image of the plate.

Diaphragm $B$ is placed in the focal plane of the lens $C_{1}$; the eye of the observer in the focus $E$ of lens $C_{2}$ 